\title{
Geminiviruses Associated with the Weed Species Ageratum conyzoides, Centipeda minima, Porophyllum ruderale, and Spilanthes iabadicensis from Java, Indonesia
}

\author{
RIKA MELIANSYAH ${ }^{1,2}$, SRI HENDRASTUTI HIDAYAT ${ }^{*}$, , AND KIKIN HAMZAH MUTAQIN ${ }^{1}$ \\ ${ }^{I}$ Department of Plant Protection, Faculty of Agriculture, Institut Pertanian Bogor, \\ Darmaga Campus, Bogor 16680, Indonesia; \\ ${ }^{2}$ Department of Agrotechnology, Faculty of Agriculture, Universitas Pajajaran, \\ Jalan Raya Bandung - Sumedang Km 2140600, Jatinangor, Bandung UBR 40600, Indonesia
}

\begin{abstract}
Geminivirus has a wide host range including cultivated plants and weeds. Infected weeds may play an important role in disease epidemic. Unfortunately, little is known about weeds species that may serve as alternative host for Geminivirus. This research was conducted to identify Geminivirus on weeds around chili pepper field to study their potential role as virus reservoir. Field surveys were conducted to chilli pepper growing area in West and Central Java Provinces, and The Special Province of Yogyakarta during 2009 to collect symptomatic weed plants. Geminivirus infection was detected using PCR technique from 9 weed samples, i.e. 5 samples Ageratum conyzoides from Bogor (AgrBgr), Sukabumi (AgrSkm), Magelang (AgrMgl), Sleman (AgrJgy), and Garut (AgrGrt); Centipeda minima from Magelang (CtpMgl); A. boehmerioides from Sleman (AcpJgy); Porophyllum ruderale from Bogor (PrlBgr); Spilanthes iabadicensis from Magelang (SplMgl). Further genetic analysis showed that those geminiviruses can be differentiated into 2 clusters, showing the possible genetic differences among them. They neither have a close relationship with other geminiviruses published earlier in the GenBank, indicating weed infecting Geminivirus collected in this study is possibly a distinct Geminivirus.
\end{abstract}

Key words: Begomovirus, Geminivirus, polymerase chain reaction, weed species

Geminivirus memiliki kisaran inang yang luas termasuk berbagai tanaman budi daya maupun gulma. Hingga saat ini pengetahuan tentang jenis-jenis gulma yang berpotensi menjadi sumber Geminivirus masih sangat terbatas. Penelitian ini dilakukan dengan tujuan mengidentifikasi Geminivirus pada gulma-gulma yang tumbuh di sekitar pertanaman cabai dalam upaya mempelajari perannya sebagai sumber inokulum virus. Survei lapangan telah dilakukan pada tahun 2009 ke beberapa daerah penanaman cabai di Provinsi Jawa Barat, Jawa Tengah, dan Daerah Istimewa Yogyakarta untuk mengumpulkan gulma-gulma yang menunjukkan gejala. Infeksi Geminivirus berhasil dideteksi menggunakan teknik PCR dari 9 sampel gulma, yaitu 5 sampel Ageratum conyzoides masing-masing dari Bogor (AgrBgr), Sukabumi (AgrSkm), Magelang (AgrMgl), Sleman (AgrJgy), dan Garut (AgrGrt), Centipeda minima dari Magelang (CtpMgl), A. boehmerioides dari Sleman (AcpJgy), Porophyllum ruderale dari Bogor (PrlBgr), Spilanthes iabadicensis dari Magelang (SplMgl). Analisis genetika lebih lanjut menunjukkan bahwa Geminivirus yang menginfeksi gulma-gulma tersebut dapat dibedakan menjadi 2 kelompok besar yang merupakan indikasi adanya keragaman genetika di antara mereka. Geminivirus yang menginfeksi spesies gulma yang berbeda tersebut tidak memiliki hubungan kekerabatan yang dekat dengan geminivirus lain yang dilaporkan dalam GenBank sehingga Geminivirus yang diidentifikasi dari spesies gulma tersebut merupakan Geminivirus yang berbeda..

Kata kunci: Begomovirus, Geminivirus, polymerase chain reaction, gulma

Geminiviruses are single-stranded DNA viruses with geminate particle morphology. They are classified into four genera (Mastrevirus, Curtovirus, Topocuvirus, and Begomovirus) on the basis of host range, insect vector and genome organization (Fauquet and Stanley 2005). Most of the geminiviruses are transmitted by whiteflies and belong to the genus Begomovirus. These species have been reported to cause significant economic yield losses to many crops in tropical and subtropical regions of the world. Member of Begomovirus was known to have enormous diversity resulting from their widespread geographic distribution and host adaptation (Varma and Malathi 2003).

Diseases caused by Begomovirus in Indonesia has been reported including those infecting tobacco

*Corresponding author, Phone: +62-251-8629363 Fax: +62-251-8629362, E-mail: srihendrastutihidayat@gmail.com
(Trisusilowati et al. 1990), tomato (Sukamto et al. 2005; Kon et al. 2006; Santoso et al. 2008), chilli pepper (Sulandari et al. 2006; Hidayat et al. 2006; Trisno et al. 2009), and also a weed species Ageratum conyzoides (Haerani and Hidayat 2003; Kon et al. 2007). Among those diseases, the most concerned one is pepper yellow leaf curl disease which induces symptoms involving foliar chlorosis and curling, reduced leaf size, inhibited fruit set and abnormal fruit. Emergence of pepper yellow leaf curl disease in Indonesia was first reported in 1999 in West Java (Rusli et al. 1999), and in 2003 the disease had been widely spread in Java with the highest incidence and severity occurred particularly in Central Java (Sulandari et al. 2006). Census data for the period from $2001-2003$ shows that the disease has undergone a 4.6 fold increase between 2001 and 2002 and a 2.5 fold increase between 2002 and 2003 (Indonesian Ministry of 
Agriculture 2003, unpublished data). It was believed that two main factors may contribute to the spread and distribution of the disease in Indonesia, i.e. fluctuation of whitefly population and the presence of alternative plants that may act as virus reservoirs.

It was reported previously that weed species may serve as alternative hosts for geminiviruses. Yang et al. (2008) identified a distinct Begomovirus species from Emilia sonchifolia from Fujian province, China; whereas Wu et al. (2007) was successfully isolated a monopartite geminivirus from $M$. coromandelianum from Guangdong, China. Three weed species (Sida spp., Macroptilium lathyroides, and Wissadula amplissima) were identified as potential Begomovirus's alternative host in Jamaica (Roye and McLaughlin 1997); meanwhile in Indonesia Sulandari et al. (2006) reported that Hyptis brevipes, Physalis floridana, Crotalaria juncea, Ageratum conyzoides were very susceptible to geminivirus infection. Thus, to build more information on the potency of weed species as virus reservoirs especially for pepper yellow leaf curl disease in Java, surveys were carried out in 2009 in West and Central Java. To this aim, weed samples showing leaf curl and yellow vein symptoms were collected from different chilli pepper growing area. In this paper, we report the identification of geminivirus associated with yellow disease of 4 weed species: A. conyzoides, Centipeda minima, Porophyllum ruderale, and Spilanthes iabadicensis.

\section{MATERIALS AND METHODS}

Virus Sources and DNA Extraction. Naturally infected weed species with yellow vein symptoms were observed in West Java (Bogor, Sukabumi, Garut), Central Java (Magelang), and Yogyakarta (Sleman). The specific symptoms was observed in Compositae weed species (A. conyzoides, C. minima, E. prostrate, P. ruderale, S. iabadicensis, G. peruviana), Euphorbiaceae species (Croton hirtus), Convolvulaceae species (Ipomoea triloba), and Onagraceae species (Ludwigia peruviana). Viral DNA was extracted from all samples as described by Kon et al. (2002).

PCR-Based Detection Using Geminivirus Specific Primers. Total DNA was extracted from symptomatic leaves according to Kon et al. (2002). The DNA pellet was resuspended in $100 \mu \mathrm{L}$ TE buffer. Amplification of geminivirus genome was proceeded using a pair of specific primers designed for the amplification of coat protein gene, CP Protein-V1 (5' TAATTCTAGATGTCGAAGCGACCCGCCGA $3{ }^{\prime}$ ) and CP Protein-C1(5' GGCCGAATTTCTTAATTTT GAACAGAATCA 3'). These specific primers were

Table 1 List of geminiviruses used for viral sequence analysis

\begin{tabular}{|c|c|c|c|c|}
\hline Geminivirus & Acronim & Geographic Location & $\begin{array}{l}\text { Sequence Length } \\
\text { (bp) }\end{array}$ & $\begin{array}{c}\text { GenBank Accession } \\
\text { No. }\end{array}$ \\
\hline Ageratum conyzoides -Bogor & AgrBgr & Indonesia : Bogor, West Java & 864 & NS \\
\hline Ageratum conyzoides -Sukabumi & AgrSkm & Indonesia : Sukabumi, West Java & 993 & NS \\
\hline Ageratum conyzoides -Magelang & AgrMgl & $\begin{array}{l}\text { Indonesia : Magelang, Central } \\
\text { Java }\end{array}$ & 868 & NS \\
\hline Ageratum conyzoides -Sleman & AgrJgy & Indonesia : Sleman, Jogyakarta & 843 & NS \\
\hline Spilanthes iabadicencis- Magelang & SplMgl & $\begin{array}{l}\text { Indonesia : Magelang, Central } \\
\text { Java }\end{array}$ & 890 & NS \\
\hline Centipeda minima- Magelang & CtpMgl & $\begin{array}{l}\text { Indonesia : Magelang, Central } \\
\text { Java }\end{array}$ & 756 & NS \\
\hline Porophyllum ruderale -Bogor & PrlBgr & Indonesia : Bogor, West Java & 832 & NS \\
\hline Bean yellow dwarf virus & BYDV & South Africa & 2566 & DQ458791 \\
\hline Tomato leaf curl Java virus & TLCJV & Indonesia : Java & 2752 & AB100304 \\
\hline \multirow[t]{2}{*}{ Tomato leaf curl Java virus-[Ageratum] } & TLCJV- & Indonesia : Java & & \\
\hline & [Ageratum] & & 2747 & AB162141 \\
\hline Tomato leaf curl Malaysia virus & TLCV & Malaysia & 2754 & AF327436 \\
\hline Tomato leaf curl Laos virus & TLCV & Laos & 2748 & AF195782 \\
\hline Ageratum yellow vein Taiwan virus & AYVV & Taiwan & 2734 & AF307861 \\
\hline Ageratum yellow vein China virus-[Hn2] & AYVV & China & 2768 & AJ495813 \\
\hline Chilli leaf curl virus-[Multan] & ChilCVA & Pakistan & 2754 & AF336806 \\
\hline Pepper leaf curl Bangladesh virus & PepLCV & Bangladesh & 2753 & AF314531 \\
\hline Pepper yellow leaf curl Indonesia virus & PepYLCV & Indonesia : West Java & 1560 & AB189849 \\
\hline Sida yellow vein Vietnam virus & SiYVVNV & Vietnam & 2753 & DQ641696 \\
\hline Mimosa yellow leaf curl virus & MiYLCV & Vietnam & 2757 & DQ641695 \\
\hline Malvastrum yellow vein virus-[Y47] & MYVV & China & 2731 & AJ457824 \\
\hline Malvastrum yellow vein Yunnan virus & MYVVNV & China & 2747 & AJ786711 \\
\hline
\end{tabular}

NS, the sequence has not been submitted to GenBank 
obtained from Asian Vegetable Research and Development Center (AVRDC), Taiwan. Amplification with PCR technique was carried out in a $25 \mu \mathrm{L}$ reaction mixture containing $1 \mu \mathrm{L}$ (200 $\mathrm{ng}$ ) of sample DNA solution and $1 \mu \mathrm{L}(0.2 \mu \mathrm{M})$ of each primer using Ready To $\mathrm{Go}^{\mathrm{TM}}$ PCR kit (Amersham Life Science). PCR was performed in thermalcycler Gen Amp PCR System9700 (Perkin Elmer) with 30 cycles of melting, annealing and DNA extension at $94^{\circ} \mathrm{C}$ for $1 \mathrm{~min}, 55^{\circ} \mathrm{C}$ for $1 \mathrm{~min}$, and $72^{\circ} \mathrm{C}$ for $2 \mathrm{~min}$, respectively. PCR products were then analysed by electrophoresis in $1 \%$ agarose gels in Tris-EDTA buffer $(0.5 \mathrm{x})$ and visualized under UV transilluminator (Maniatis etal. 1982).

Sequence analysis. DNA fragments of approximately $760 \mathrm{bp}$, as a product of PCR amplification, was sent to Macrogen Inc. (South Korea) for DNA sequencing by the dideoxy nucleotide chain termination method. Sequence data were then assembled and analyzed with the aid of Bioedit Programme and PAUP version 4.0 (Swofford 2002). Geminivirus sequences available from GenBank were used for phylogenetic analysisis (Table 1). The cladogram was set up with a quantitative cladistic maximum parsimony using heuristic methods. A hundred bootstrap iterations were performed.

\section{RESULTS}

\section{Amplification and Sequencing of Coat Protein}

Gene. PCR using specific primers CP Protein-V1/CP Protein-C1 was successfully amplified a $\sim 760$ base pairs of coat protein fragments from 9 symptomatic samples (Fig 1) i.e. 5 samples A. conyzoides from Bogor (AgrBgr), Sukabumi (AgrSkm), Magelang (AgrMgl), Sleman (AgrJgy), and Garut (AgrGrt); $C$. minima from Magelang (CtpMgl); A. boehmerioides from Sleman (AcpJgy); P. ruderale from Bogor
(PrlBgr); S. iabadicensis from Magelang (SplMgl). DNA fargments were not obtained from other weed samples (G. parviflora from Garut, E. prostrata from Brebes, I. triloba from Garut, and L. peruviana from Cianjur). Major constraint for PCR-based detection using weed samples occurred on viral DNA extraction. Field samples tend to easily damage thus required immediate processing. In addition, inhibitor and secondary metabolites components found in weed tissues may inhibit the amplification process using PCR.

Nucleotide sequence data was obtained from 7 virus samples (Table 1). Nucleotide's length of the virus that was successfully sequenced and used for sequence comparison was in the range of 756 to $993 \mathrm{bp}$, which contains parts of geminivirus coat protein gene (Santoso et al. 2008).

Analysis of Genetic Relationship. Coat protein fragment analysis showed that weed-infecting geminiviruses collected from this study can be differentiated into 2 groups (Fig 2). The first group consists of 6 weed-infecting geminiviruses from this study (AgrBgr, AgrSkm, AgrJgy, AgrMgl, SplMgl, and (tpMgl) with a 100 bootstrap value, and the second group consists of one weed-infecting geminivirus from this study (PrlBgr) and other geminiviruses previously reported in GenBank with a 92 bootstrap value.

Further more, the virus isolates in the first group can be differentiated into 4 subgroups each consisting of AgrBgr and AgrSkm, AgrJgy alone, AgrMgl and SplMgl, and CtpMgl alone. In the second group the virus isolate PrlBgr was placed in the different sub group with other weed-infecting geminiviruses. None of the weed infecting geminiviruses collected from this study has close relationship with geminiviruses previously reported from Java, Indonesia (TLCV, TLCV-[Ageratum], PepYLCV).

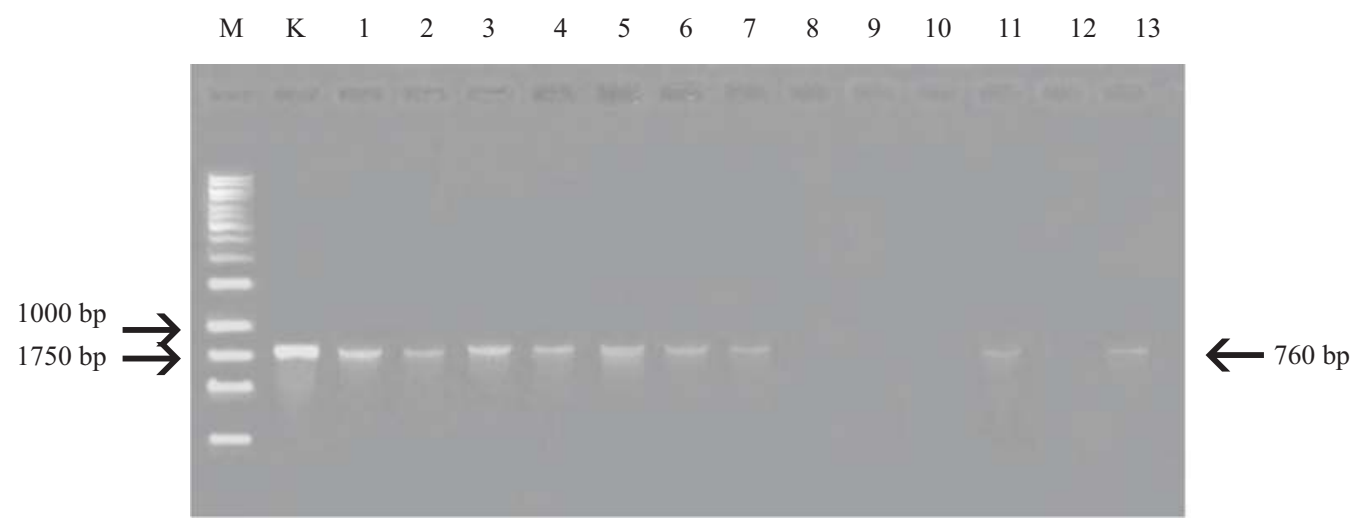

Fig 1 Amplification product of geminiviral DNA fragment using specific primers CP Protein-V1/CP Protein-C1. The samples consist of weed-infecting geminiviruses : K. Positive control (artificially inoculated geminivirus from A. conyzoides); 1. A. conyzoides-Bogor; 2. A. conyzoides-Sukabumi; 3. A. conyzoides-Magelang; 4. A. conyzoides-Sleman; 5. A. conyzoides-Garut; 6. S. iabadicencis-Magelang; 7. C. minima-Magelang; 8. E. prostrata-Brebes; 9. G. parviflora-Garut; 10.I. triloba-Garut; 11. A. conyzoides-Jogyakarta, 12; L. peruviana-Cianjur; 13.P. ruderale-Bogor; M. 1 kb DNAladder. 


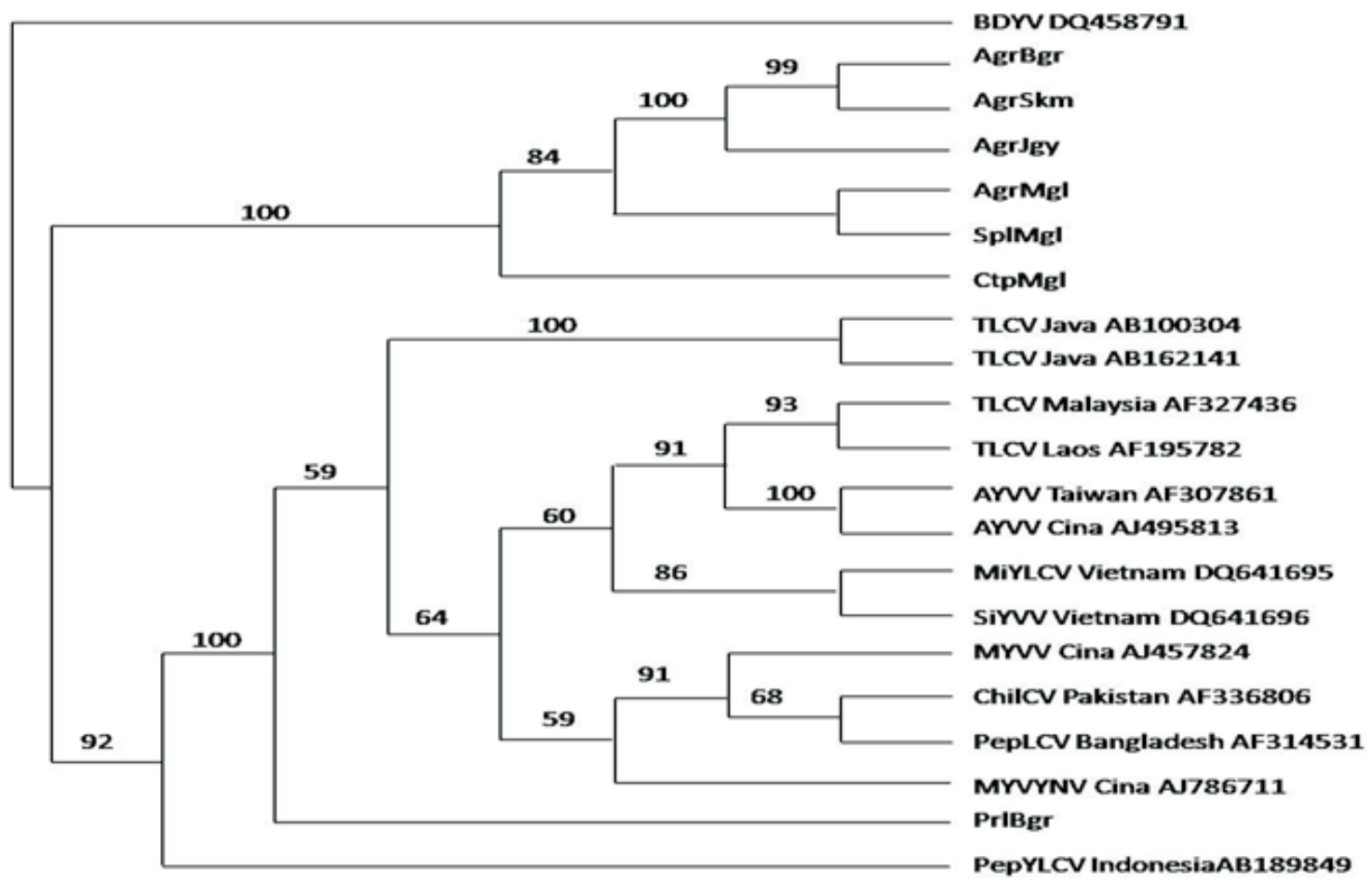

Fig 2 Cladogram showing the interrelationship among weed-infecting geminiviruses and relative geminivirus' species based on allignment of part of coat protein gene's nucleotide sequence. Boothstrap value (100 replication) are shown on the branch of cladogram. Bean Yellow Dwarf Virus (BYDV) is included as outgroup. $\mathrm{AgrBgr}=$ A. conyzoides -Bogor, $\mathrm{AgrSkm}=A$. conyzoides-Sukabumi, $\mathrm{AgrMgl}=$ A. conyzoides $=\mathrm{Magelang}, \mathrm{AgrJgy}=$ A. conyzoidesSleman, $\mathrm{SplMgl}=$ S. iabadicencis-Magelang, CtpMgl $=$ C. minima-Magelang, PrlBgr $=$ P. ruderale-Bogor, BYDV = Bean yellow dwarf virus from South Africa (DQ458791), TLCV Java = Tomato leaf curl Java virus from Java, Indonesia (AB100304), TLCV Java = Tomato leaf curl Java virus-[Ageratum] from Java, Indonesia (AB162141), TLCV Malaysia = Tomato leaf curl Malaysia virus segment A from Malaysia (AF327436), TLCV Laos = Tomato leaf curl Laos virus from Malaysia $($ AF195782), AYVV Taiwan = Ageratum yellow vein Taiwan virus from Taiwan $($ AF307861 $)$, AYVV China $=$ Ageratum yellow vein China virus from China (AJ495813), ChilCVA = Chili leaf curl virus-[Multan] from Pakistan (AF336806), PepLCV = Pepper leaf curl Bangladesh virus segment A from Bangladesh (PAF314531), PepYLCV = Pepper yellow leaf curl Indonesia virus from West Java, Indonesia (AB189849), SiYVV = Sida yellow vein virus from Vietnam (SiYVV DQ641696), MiYLCV = Mimosa yellow leaf curl virus from Vietnam (DQ641695), MYVV= Malvastrum yellow vein virus from China (AJ457824), MYVYnV= Malvastrum yellow vein Yunnan virus from China (Aj786711).

\section{DISCUSSIONS}

Weeds are potential sources of primary inoculum of viruses and play an important role in their persistence and spread (Hallan et al. 1998). Weed infecting geminiviruses has been reported from different geographic location especially in the region where the geminivirus infection causing significant yield loss in important crops. Roye and McLaughlin (1997) reported a distinct geminivirus species from Sida spp., Macroptilium lathyroides, and Wissadula amplissima when they studied the role of weed species in the establishment of tomato and pepper diseases due to Geminivirus infection in Jamaica. Artificial inoculation using Bemisia tabaci involving several weed species was conducted by Sulandari et al. (2006) to determine the host range of pepper infecting geminivirus and concluded that $H$. brevipes, $P$. floridana, $C$. juncea, A. conyzoides were very susceptible to PepYLCV infection. Yellow vein symptom or leaf netting is commonly found associated with geminivirus infection on weed species. During field survey to chilli pepper growing area in 2009, we easily found $A$. conyzoides showing yellow vein symptom. Evidence of Geminivirus infection on $A$. conyzoides in Indonesia has been reported previously by Haerani and Hidayat (2003), Sukamto et al. (2005), and Kon et al. (2007). New Geminivirus infection on weed species in Indonesia was reported in this paper, i.e. Geminivirus infecting C. minima, P. ruderale, and S. iabadicensis.

Preliminary reports indicated that the primary Geminiviruses infecting weeds are not the same ones that infect crops (Gilbertson et al. 1991; Mc Laughlin et al. 1994), although it has been speculated that a number of common weeds may serve as alternate hosts for crop-infecting geminiviruses. Based on phylogenetic analysis, Roye and McLaughlin (1997) concluded that weed-infecting geminiviruses are not host to cropinfecting geminiviruses in Jamaica. Similarly, phylogenetic relationships of the weed-infecting viruses collected in this study with other geminiviruses indicate that crop- and weed-infecting geminiviruses from Java, Indonesia are distinct, and highly diverse. Despite all seven weed-infecting geminiviruses were collected from endemic area of pepper yellow leaf curl disease in Java, none of them has a close relationship with PepYLCV Indonesia. Based on our phylogenetic analysis, it is evident that A. conyzoides, $C$. minima, $P$. 
ruderale, and $S$. iabadicensis are not reservoirs for geminiviruses important on chilli pepper and tomato in Java. However, our host range study showed that PepYLCV was able to infect Ludwigia peruviana, $A$. conyzoides, S. iabadicensis, P. ruderale, Synedrella nodiflora, and Galinsoga parviflora (data not published). Earlier, Kon et al. (2007) found evidence for interspecies recombination between Tomato leaf curl Java virus (ToLCJV) and a strain of Ageratum yellow vein virus (AYVV - [Java]). Therefore, the importance of weeds as alternative hosts for cropinfecting geminiviruses in Indonesia will need further investigation. These results may significantly affect the development of strategies for managing the spread of these geminiviruses.

\section{ACKNOWLEDGEMENTS}

This work was supported by the Australian Center for International Agricultural Research (Project No. HORT/2004/048), and Competitive Research Grant, Ministry of National Education, Republic of Indonesia (DIPA No. 0041/023-04.1/-/2010). We are grateful to Sri Sudarmiyati Tjitrosoedirdjo for her assistance in weed identification.

\section{REFERENCES}

Fauquet CM, Stanley J. 2005. Revising the way we conceive and name viruses below the species level: a review of geminivirus taxonomy calls for new standardized isolate descriptors. Arch Virol. 150 (10):21512179. doi:10.1007/s00705-005-0583-0.

Gilbertson RL, Hidayat SH, Martinez RT, Leong SA, Faria JC, Morales F, Maxwell DP. 1991. Differentiation of bean infecting geminiviruses by nucleic acid hybridization probe and aspects of bean golden mosaic in Brazil. Plant Dis. 75(4):336-342. doi:10.1094/PD-75-0336.

Haerani, Hidayat SH. 2003. Geminivirus penyebab penyakit kuning pada babadotan (Ageratum conyzoides L.): deteksi molekuler dan studi penularan pada beberapa tanaman Solanaceae [Geminivirus causing yellow disease on Ageratum conyzoides : molecular detection and transmission study on some solanaceae plants]. J Fitopatol Indones. $7(2): 65-70$

Hallan V, Saxena S, Singh BP. 1998. Ageratum, croton and malvastrum harbour geminiviruses: evidence through PCR amplification. World J Microbiol Biotech. 14(6): 931-932.

Hidayat SH, Chatchawankanpanich O, Rusli E, Aidawati N. 2006. Begomovirus associated with pepper yellow leaf curl disease in West Java, Indonesia. J Mikrobiol Indones. 11(2):87-89

Kon T, Kuwabara K, Hidayat SH, Ikegami M. 2007. A Begomovirus associated with ageratum yellow vein disease in Indonesia: evidence for natural recombination between Tomato leaf curl
Java virus and Ageratum yellow vein virus-[Java]. Arch Virol. 152(6):1147-1157. doi:10.1007/s00-705-006-0928-3.

Kon T, Hidayat SH, Hase S, Takahashi H, Ikegami M . 2006. The natural occurrence of two distinct begomoviruses associated with DNA and a recombinant DNA in a tomato plant from Indonesia. Phytopathology 96(5):517-525. doi:10.1094/PHYTO-96-0517.

Kon T, Dolores LM, Murayama. 2002. Genome organization of an infectious clone of Tomato leaf curl virus (Philippines), a new monopatite Begomovirus. Phytopathology 150(11-12):587-591. doi:10.046/J.1439-0434.2002.00817.x.

Maniatis T, Fritsch EF, Sanbrook J. 1982. Molecular cloning: a laboratory manual. Cold Spring Harbor (US): Cold Spring Harbor Lab Pr.

McLaughlin W, Rojas MR, Nakhla MK, Hidayat SH, Maxwell DP. 1994. Partial molecular characterization of bean golden mosaic virus isolates from Jamaica and Central America. Plant Dis. 78(12):1220. doi:10.1094/PD-78-1220C.

Roye ME, McLaughlin WA. 1997. Genetic diversity among geminiviruses assoated with the weed species Sida spp., Macropilium lathyroides, and Wissadula amplissima from Jamaica. Plant Dis. 81(11):12511258. doi:10.1094/PDIS.1997.81.11.1251.

Rusli ES, Hidayat SH, Suseno R, Tjahjono B. 1999. Geminivirus on pepper: Symptom variation and transmission study. Bul Hama Penyakit Tumb.11(1):126-131.

Santoso TJ, Hidayat SH, Herman M, Aswidinnoor H, Sudarsono. 2008 Identifikasi dan keragaman genetik berasosiasi dengan penyakit keriting pada tomat berdasarkan teknik (PCR)-(RFLP) [Identification and genetic diversity of Begomovirus associated with leaf curl disease on tomato based on polymerase chain reaction (PCR) restriction fragment length polymorphism (RFLP) technique]. J Agrobiogen. 4(1):9-17.

Sukamto, Kon T, Hidayat SH, Ito K, Hase S, Takahashi H, Ikegami M. 2005. Begomovirus associated with leaf curl disease of tomato in Java, Indonesia. J Phytopathology 153(9):562-566. doi:10.1111/J.14390434.2005.01020.x

Sulandari S, Suseno R, Hidayat SH, Harjosudarmo J, Sosromarsono S. 2006. Deteksi dan kajian kisaran inang penyebab penyakit daunkriting kuning cabai [Detection and host range study of Geminivirus causing pepper yellow leaf curl disease]. Hayati 13(1): 1-6.

Swofford DL. 2002. PAUP*. Phylogenetic Analysis Using Parsimony (*and other methods). Version 4. Sinauer Associates, Sunderland, Massachusetts.

Trisno J, Hidayat SH, Habazar T, Manti I, Jamsari. 2009. Detection and sequence diversity of Begomovirus associated with Yellow Leaf Curl Diseases of Pepper (Capsicum annuum) in West Sumatra, Indonesia. Microbiol Indones. 3(2):61-66.

Trisusilowati EB, Suseno S, Sosromarsono S, Barizi, Soedarmadi, Nur MA. 1990. Transmissions, serological aspects and morphology of the tobacco krupuk virus. Indones J Agriculture. 1(2):38-42.

Wu J, Mugiira RB, Zhou X. 2007. Malvastrum leaf curl Guangdong virus is a distinct monopartite Begomovirus. Plant Pathol 56(5): 771-776. doi:10.1111/J.1365-3059.2007.01682.x.

Yang CX, Cui GJ, Zhang J, Weng XF, Xie LH, Wu ZJ. 2008. Molecular characterization of a distinct Begomovirus species isolated from Emilia sonchifolia. J Plant Pathol. 90(3):475-478.

Varma A, Malathi VG. 2003. Emerging geminivirus problems: a serious threat to crop production. Ann Appl Biol 142(2):145-164. doi:10.1111/J.1744-7348.2003.tb00240.x. 